\title{
Seasonality of dung beetles (Coleoptera: Scarabaeinae) in Atlantic Forest sites with different levels of disturbance in southern Brazil
}

\author{
Sheila Cassenote' (1D), Pedro Giovâni da Silva² (iD, Rocco Alfredo Di Mare ${ }^{3, \dagger}$ \& Andressa Paladini ${ }^{3}$
}

\begin{abstract}
1.Programa de Pós-Graduação em Biodiversidade Animal, Universidade Federal de Santa Maria, 97110-970 Santa Maria, RS, Brazil. (cassenottesheila@gmail.com) 2. Programa de Pós-Graduação em Ecologia, Conservação e Manejo da Vida Silvestre, Universidade Federal de Minas Gerais, $31270-910$ Belo Horizonte, MG, Brazil. 3. Departamento de Ecologia e Evolução, Universidade Federal de Santa Maria, 971 10-970 Santa Maria, RS, Brazil.

$\dagger$ in memoriam
\end{abstract}

Received 18 February 2019

Accepted 14 August 2019

Published 21 October 2019

DOI 10.1590/1678-4766e2019035

\begin{abstract}
Dung beetle species were collected between May 2016 and July 2017 with pitfall traps baited with human feces in four Atlantic Forest sites with different levels of disturbance in the state of Rio Grande do Sul, southern Brazil. We sampled 5,535 individuals belonging to 46 species. Canthidium aff. trinodosum (20.71\%), Eurysternus parallelus Castelnau, 1840 (14.82\%), Onthophagus catharinensis Paulian, 1936 (12.09\%), Scybalocanthon nigriceps (Harold, 1868) (7.61 \%), Eurysternus caribaeus (Herbst, 1789) (7.49\%), and Canthon rutilans cyanescens Harold, 1868 (7.22\%) were the most abundant species, which represented $70 \%$ of the individuals sampled. Moreno Fortes Biological Reserve had the higher richness and Morro do Cerrito the higher abundance, while Val Feltrina presented the lowest values. The greatest similarity occurred between Turvo State Park and Moreno Fortes Biological Reserve, while Moreno Fortes Biological Reserve and Val Feltrina had the lowest similarity. Only 11 species (23.9\%) occurred in all sites, while 14 species were restricted to only one of the fragments. Both abundance and richness of dung beetles were positively correlated with site temperature but not with precipitation.
\end{abstract}

KEYWORDS. Species diversity, subtropical climate, temporal patterns.

RESUMO. Sazonalidade dos rola-bostas (Coleoptera: Scarabaeinae) em sítios de Mata Atlântica com diferentes níveis de perturbação no sul do Brasil. Espécies de rola-bostas foram coletadas entre maio de 2016 e julho de 2017 com armadilhas de queda iscadas com fezes humanas em quatro localidades de Mata Atlântica com diferentes níveis de perturbação no estado do Rio Grande do Sul, sul do Brasil. Foram amostrados 5.535 indivíduos pertencentes a 46 espécies. Canthidium aff. trinodosum (20,71\%), Eurysternus parallelus Castelnau, 1840 (14,82\%), Onthophagus catharinensis Paulian, 1936 (12,09\%), Scybalocanthon nigriceps (Harold, 1868) (7,61\%), Eurysternus caribaeus (Herbst, 1789) (7,49\%) e Canthon rutilans cyanescens Harold, 1868 (7,22\%) foram as espécies mais abundantes, que representaram 70\% dos indivíduos amostrados. A Reserva Biológica Moreno Fortes teve a maior riqueza e o Morro do Cerrito a maior abundância, enquanto Val Feltrina apresentou os menores valores. A maior similaridade ocorreu entre o Parque Estadual do Turvo e a Reserva Biológica Moreno Fortes, enquanto a Reserva Biológica Moreno Fortes e a Val Feltrina tiveram a menor similaridade. Apenas 11 espécies $(23,9 \%)$ ocorreram em todos os locais, enquanto 14 espécies foram restritas a apenas um dos fragmentos. Tanto a riqueza como a abundância de Scarabaeinae foram positivamente correlacionadas com a temperatura do local, mas não com a precipitação.

PALAVRAS-CHAVE. Diversidade de espécies, clima subtropical, padrões temporais.

Dung beetles (Coleoptera: Scarabaeinae) constitute a group that comprises most coprophagous species that act in important ecosystem functions such as nutrient recycling, soil hydration and aeration, secondary seed dispersal, and natural control of organisms that develop on mammal feces (NiCHOLS et al., 2008). Another important ecological role developed by these insects is their use as bioindicators because they are very sensitive environmental changes (NICHOLS et al., 2007). This group of beetles is found in almost all terrestrial biomes, with more than 6,200 species distributed in 267 genera; but it is estimated that 30 to $50 \%$ of the total species of this group have not been described yet (TARASOV \& GÉNIER, 2015). In Brazil, 726 species are recorded in 63 genera (VAZ-DE-MeLLO, 2019), and this number can double with new surveys and reviews of several groups (VAZ-DE-MELLO, 2000).
The pattern of occurrence of higher insect richness and abundance during high temperatures is widespread, especially in temperate regions, where insects usually decrease their activities when there is a predominance of low temperatures and increase them at higher temperatures (WOLDA, 1988; BEGON et al., 2007). This temporal pattern was observed for Scarabaeinae assemblages of prairies in Uruguay, where average air and soil temperature were the determining factors driving the richness and abundance of dung beetles (MORELLI et al., 2002). Besides, DA SiLva et al. (2013) also found correlation between dung beetle richness and abundance with monthly temperature but nor with precipitation or relative humidity in sites of Atlantic Forest in southern Brazil.

However, precipitation can also play a role in both tropical (ANDRESEN, 2005) and subtropical regions 
(Hernández \& VAZ-DE-Mello, 2009; Авот et al., 2012) driving dung beetle temporal distribution. For example, SALOMÃo \& IANNUZZI (2015) found Dichotomius aff. sericeus as the dominant species in a study carried out in forest fragments of the Brazilian state of Pernambuco, with greater abundance during the rainy season (with two-thirds of the total of specimens captured during this season). Precipitation also influenced other species with low abundance. Therefore, separately or jointly, temperature and precipitation drive the temporal distribution of dung beetles, a pattern that agrees with other studies on seasonality of Neotropical dung beetles (DA Silva et al., 2011; AUDINO et al., 2011; DA SILVA \& Di MARE, 2012; LiMA et al., 2015).

In this study, we aimed to describe the seasonality of dung beetles by sampling individuals monthly along an entire year in a subtropical region of Southern Brazil. We surveyed dung beetles in four Atlantic Forest sites with different levels of disturbance, two of them Conservation Units and other two being fragments of forest disturbed by anthropogenic activities. We described spatiotemporal patterns of species richness, abundance, and composition of the dung beetle assemblages.

\section{MATERIAL AND METHODS}

Study area. The study was developed in four Atlantic Forest sites with different levels of alteration located in southern Brazil (Fig. 1). Two sites are Conservation Units (Turvo State Park and Moreno Fortes Biological Reserve) and two sites are fragments disturbed by anthropogenic activities (Morro do Cerrito and Val Feltrina). The first two sites are in the northwest of the Rio Grande do Sul state, while the other two sites are in the central region of the Rio Grande do Sul state, southern Brazil. Each site is described as follows.
Turvo State Park. With an area of 17,491 ha, the Turvo State Park (278'44'’S, 5353'10”'W) (TSPK, Fig. 1a) is located in the Derrubadas municipality, in the "Planalto" region of the Rio Grande do Sul, on the border with the state of Santa Catarina and Argentina. The area is classified as a phytoecological region of the Decidual Seasonal Forest in the Uruguay River Valley (IBGE, 2012), with altitudes varying between 100 and $400 \mathrm{~m}$. The region is classified as Cfa climate (KUINCHTNER \& BURIOL, 2001), with an annual average temperature of $18.8^{\circ} \mathrm{C}$. The average temperature of the hottest month (January) is $22^{\circ} \mathrm{C}$ and in the coldest month (July) the temperature ranges from $-3^{\circ} \mathrm{C}$ to $18^{\circ} \mathrm{C}$ (ICMBio, 2005). Annual precipitation is $1787 \mathrm{~mm}$ (MALUF, 2000). The park is the last refuge for animals such as jaguar, tapir and harpy in the state of Rio Grande do Sul. For such attributes it is considered as the most important area for the conservation of the endangered fauna. Currently, the Park stands out as the last significant portion of the plant formation of "Alto Uruguai" in the State (ICMBIo, 2005).

Moreno Fortes Municipal Biological Reserve. The Moreno Fortes Municipal Biological Reserve in Dois Irmãos

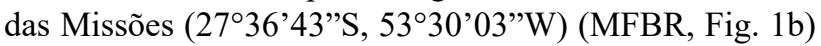
belongs to the physiographic region denominated as "Médio Alto Uruguai", with altitudes varying between 400 and 600 $\mathrm{m}$. Its area is $\sim 458 \mathrm{ha}$. The climate is Cfa (KuINCHTNER \& BURIOL, 2001) and temperature varies between $28^{\circ} \mathrm{C}$ and $35^{\circ} \mathrm{C}$ in the warmer months and between $-3^{\circ} \mathrm{C}$ and $17^{\circ} \mathrm{C}$ in the colder months. The average rainfall is $1600 \mathrm{~mm}$ per year, where the highest rainy months are April, May, June, and October. A mix of Mixed Forest (i.e., Araucaria forest) and Deciduous Forest characterizes the vegetation (ICMBio, 2008).

Morro do Cerrito. Located in the eastern region of the Santa Maria municipality $\left(29^{\circ} 42^{\prime} 07^{\prime \prime}\right.$ S, $\left.53^{\circ} 47^{\prime} 08^{\prime \prime} W\right)$, the

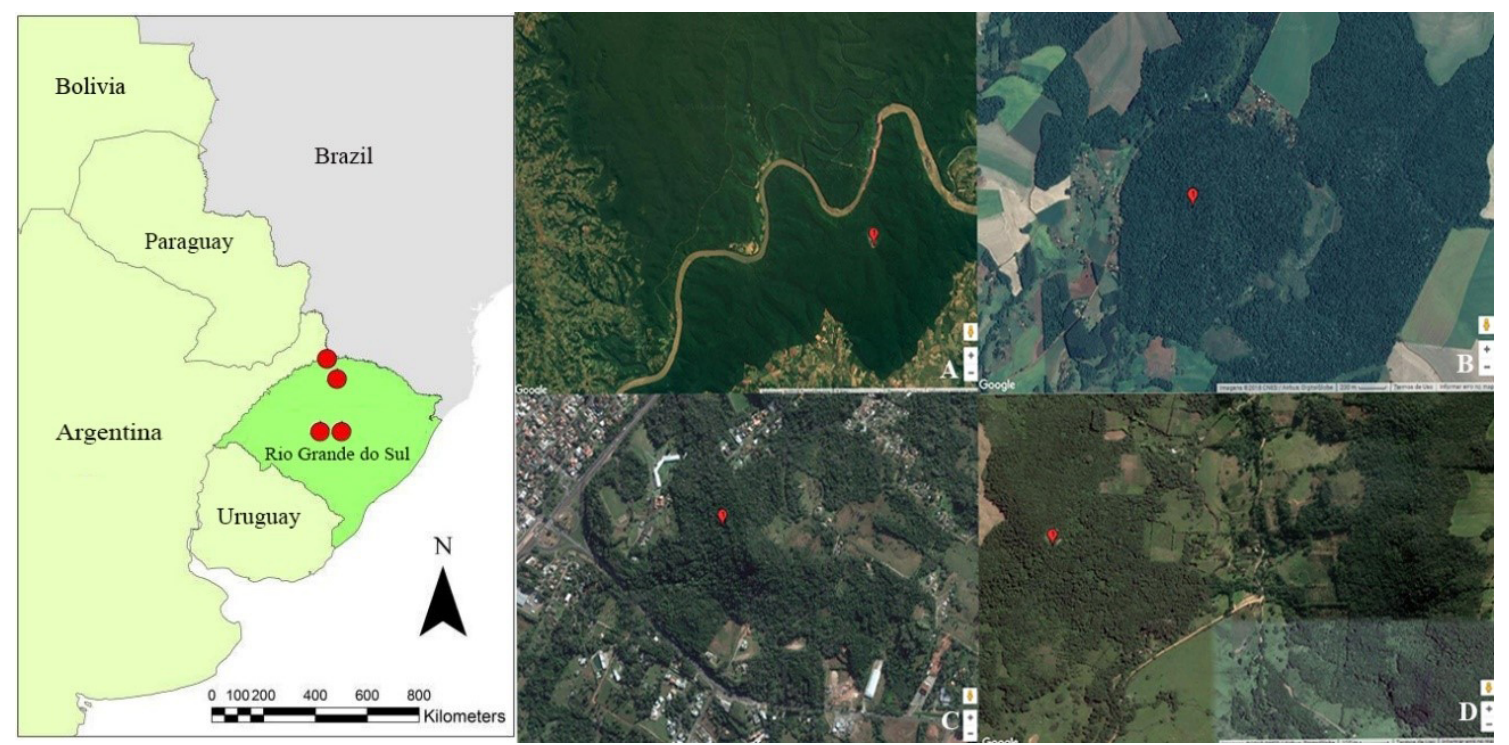

Fig. 1. Location of the four Atlantic Forest sites sampled in Rio Grande do Sul state, Brazil, map and satellite images: A, Turvo State Park, Derrubadas; B, Moreno Fortes Biological Reserve, Dois Irmãos das Missões; C, Morro do Cerrito, Santa Maria; D, Val Feltrina, Silveira Martins. Source: ArcGIS software map; satellite images Google Earth Explorer. 
Morro do Cerrito (MOCE, Fig. 1c) is an isolated remnant of the Decidual Seasonal Forest belonging to the Central Depression of Rio Grande do Sul (Pereira et al., 1989). It has an area of $\sim 141.5$ ha and an average altitude of 169 $\mathrm{m}$. The climate is Cfa (Kuinchtner \& Buriol, 2001). The temperature varies between $27^{\circ} \mathrm{C}$ and $30^{\circ} \mathrm{C}$ in the warmer months and between $10^{\circ} \mathrm{C}$ and $12^{\circ} \mathrm{C}$ in the colder months (INMET, 2018). The annual precipitation of 1708 $\mathrm{mm}$ and average annual temperature of $19.2^{\circ} \mathrm{C}$ (MALuF, 2000). In the last decades, with the increasing expansion of the municipality, its environment was dominated by constructions, and consequently, exotic trees are present in the border and the interior of the fragment. The number of neighboring fragments, usually composed of native vegetation, is high, but the average distance to them is also large, making MOCE increasingly isolated resulting in a forest fragment with an intermediate level of preservation.

District of Val Feltrina. The fourth site is a forest fragment in the middle of a fragmented landscape of seasonal deciduous forest in the district of Val Feltrina (VAFE)

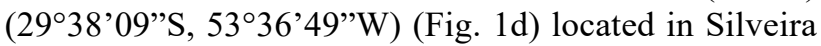
Martins municipality, Rio Grande do Sul. Its surroundings are dominated by a matrix of open areas (i.e., grasslands for cattle and corn plantations). This site is located on the slope of the border of the Brazilian Southern Plateau, in the transition area with the Central Depression of the state, with an area of $\sim 119 \mathrm{~km}^{2}$ (IBGE, 2011). The climate is also Cfa (KUINCHTNER $\&$ BURIOL, 2001). The altitude varies between 100 and $480 \mathrm{~m}$, and the average annual temperature is approximately $18^{\circ} \mathrm{C}$, with minimum temperatures close to $0^{\circ} \mathrm{C}$ and maximum temperatures close to $40^{\circ} \mathrm{C}$. The average annual precipitation varies between 1,500 and 1,700 $\mathrm{mm}$ approximately.

Sampling method. In each site, $48 \mathrm{~h}$ monthly samplings were carried out from May 2016 to July 2017, except for the TSPK, where the samplings were seasonal (N $=4$ samplings, October/2016, January, April, and July/2017). Baited pitfall traps were used to sample dung beetles. We distributed ten pairs of traps distant $100 \mathrm{~m}$ between them.

Pitfall traps were composed of a $1000 \mathrm{ml}$ plastic recipient of $11 \mathrm{~cm}$ in diameter and $8 \mathrm{~cm}$ deep, with a bait compartment and a rain cover. The plastic recipient was buried in the ground with the opening at the same level as the ground. Inside the traps, $250 \mathrm{ml}$ of liquid detergent solution were placed. Traps were baited with human excrement (about $25 \mathrm{~g}$ ), since it is the bait that attracts most dung beetle species (Filgueiras et al., 2009; DA Silva et al., 2012). The baits were placed in a smaller plastic container attached to the bottom of traps.

The captured beetles were individualized to perform the quantitative analysis by direct counting of the specimens present in each trap. Dung beetles were identified by experts. Voucher specimens were stored in the "Seção de Entomologia da Coleção Zoológica" of the Universidade Federal de Mato Grosso (UFMT), Instituto de Biociências, Cuiabá, Mato Grosso, Brazil. All necessary sampling permits were issued by Instituto Chico Mendes de Conservação da Biodiversidade (SISBIO \#54137-1).

Data analysis. The average richness and abundance of beetles were calculated for each site in each sample period. The diversity indexes used were Shannon-Wiener (H) and Simpson (1-D). The Pielou equitability index comes from the Shannon diversity index and helps to demonstrate the uniformity of the distribution of individuals among the existing species (Pielou, 1966). Its value exhibits an amplitude of 0 (minimum uniformity) to 1 (maximum uniformity). They were measured through the matrix of species abundance data in each area. Diversity indices are useful for assessing the equitable distribution of abundance among component species in each area (MAGURRAN, 2004). The diversity indices were calculated using iNEXT online (Hsien et al., 2016). A non-asymptotic approach based on interpolation and extrapolation iNEXT computes the estimated diversities for standardized samples with a common sample size or sample completeness. This approach aims to compare diversity estimates for equally-large (with a common sample size) or equally-complete (with a common sample coverage) samples; it is based on the rarefaction and extrapolation sampling curves of Hill numbers for $\mathrm{q}=$ 0 (Species richness), 1 (Shannon diversity) and 2 (Simpson diversity) (CHAO et al., 2016). The rarefaction curve based on size and extrapolation of the samples allows to verify the observed number of individuals collected and the diversity of species, also showing the extrapolation of these values to each site. We also used the Jackknife 1 richness estimator to estimate the number of species at each site. Both analyses were carried out using the software EstimateS Win 910 (Colwell \& Elsensohn, 2014).

The data of temperature and rainfall (minimum, average and maximum) from May 2016 to July 2017 for the city of Santa Maria and Silveira Martins were obtained through the website of the National Meteorological Institute (INMET), Meteorological Station of Observation of Automatic Surface of Santa Maria - A803 (7 km away from MOCE and $15 \mathrm{~km}$ from VAFE). The meteorological data of the Derrubadas municipality and Dois Irmãos das Missões municipality were obtained based on information from the Frederico Westphalen - A854 Automatic Surface Observation Weather Station, with the nearest station between the two Conservation Units. (58 km away from TSPK and $24 \mathrm{~km}$ from RBMF) With these data, a linear regression analysis was performed between the monthly abundance and richness of the four sites (response variable) and climatic variables of temperature and precipitation (predictor variables). The seasons of the year used are those defined for the southern region of Brazil in which the following periods are defined: Spring (September 22 to December 20); Summer (December 21 to March 19); Autumn (March 20 to June 20) and Winter (June 21 to September 21)

For an evaluation of similarity of the Scarabaeinae fauna between sites, the Jaccard coefficient was used (in the 
case of this index the abundance values were replaced by binary measures: $0=$ absence, $1=$ presence). The Jaccard coefficient is very useful in species presence and absence data, so the composition of the objects is evaluated with equal weights (HAMMER et al., 2001). By using the algorithm of paired groups by the mean (UPGMA) and the Jaccard similarity, a cluster analysis was performed between the four sites (spatial similarity) in the PAST software (HAMmER et al., 2001).

A Non-metric multidimensional scaling (NMDS) analysis was carried out to visualize the similarity between all samplings among the four Atlantic Forest sites (temporal similarity). In this ordination analysis, the distances are not original, because it works with ranks of distances and seeks to minimize stress through little loss of information while its algorithm gives more weight to the representation of great distances than too small ones. The ordination presents a distribution of samples in gradients. Closer samples are more similar in species composition to each other, while more distant and isolated samples present less similar species composition. Abundance data and Bray-Curtis coefficient were used in this analysis.

\section{RESULTS}

A total of 5,535 individuals belonging to 46 species were collected. Among the four sites sampled, Canthidium aff. trinodosum (20.7\%), Eurysternus parallelus Castelnau, 1840 (14.8\%), Onthophagus catharinensis Paulian, 1936 (12.1\%), Scybalocanthon nigriceps (Harold, 1868) (7.6\%), Eurysternus caribaeus (Herbst, 1789) (7.5\%), and Canthon rutilans cyanescens Harold, 1868 (7.3\%) were the species that presented the greatest abundance and together represent $70 \%$ of the collected individuals. Most sites showed a similar species richness (28-31), except for VAFE $(S=21)$. Only 11 species $(22.4 \%)$ occurred in all sites. MFRB presented the highest species richness $(\mathrm{S}=31)$ and abundance $(\mathrm{N}=$ 1,306), followed by TSPK $(\mathrm{S}=30, \mathrm{~N}=1,901)$. MOCE presented the highest abundance $(\mathrm{N}=2,180)$, but only the third largest richness $(\mathrm{S}=26)$, followed by VAFE $(\mathrm{N}=148)$.

The greatest richness was found in October/2016 ( $\mathrm{S}=19)$, as well as the highest abundance $(\mathrm{N}=1,954,35.27 \%$ of the total individuals). The lowest abundance and richness occurred in July/2016 (five species, $\mathrm{N}=71$ [1.28\%]). Among the seasons, we found the greatest abundance and richness in spring $(\mathrm{N}=2,944, \mathrm{~S}=19)$, followed by summer $(\mathrm{N}=1,603$, $\mathrm{S}=28)$ and autumn $(\mathrm{N}=623, \mathrm{~S}=14)$. The winter presented the lowest abundance and richness $(\mathrm{N}=360, \mathrm{~S}=13)$.

Only 11 species (23.9\%) occurred in all sites (Tab. I), while 14 were restricted to only one of the fragments, each with a different number of exclusive species: Ateuchus aff. apicatus (Harold, 1867) and Eurysternus aeneus Génier, 2009 occurred only in TSPK; Ateuchus aff. carbonarius (Harold, 1868), Canthon laminatus Balthasar, 1939, and Canthon sp. in MOCE; Canthon conformis Harold, 1868, Deltochilum sculpturatum Felsche, 1907, and Phanaeus splendidulus (Fabricius, 1781) in VAFE; Canthidium deplanatum Balthasar 1939, Canthidium dispar Harold 1867, Chalcocopris hesperus Olivier, 1789, Dichotomius fissus Harold, 1867, and Dichotomius sp. in MFBR.

The Shannon diversity $(\mathrm{q}=1)$ (Tab. II) presented higher values for VAFE (10.10), followed by MFRB (9.05). Similarly, the higher Simpson diversity $(\mathrm{q}=2)$ was also found in $\operatorname{VAFE~(6.61),~followed~by~MOCE~(6.00).~The~sites~with~the~}$ highest equitability were VAFE (0.75), followed by MFRB and MOCE (both with a value of 0.64), and TSPK (0.60).

The rarefaction curve based on size and extrapolation of the samples (Fig. 2) allowed to verify when the extrapolation of the number of specimens in VAFE approaches 2,200, the diversity of 30 species was estimated, for TSPK 35 , MOCE 30 and MFBR 41. Individual extrapolation curves of the four locations were shown in Fig. 3.

The Jackknife 1 estimated 39 species for TSPK, and where observed 31 ( $79.5 \%$ from estimated). For MFRB, the estimator determined 36.5 species, where we sampled 31 species $(84.9 \%)$, is the site in which the expected and observed values are close. For MOCE, the estimator determined 32.5 species and we observed 27 of them (83.1\%), For VAFE, Jackknife 1 estimated 28.25 species, in which the observed richness was 21 species (74.3\%).

In the linear regression analysis, transforming abundance values into $\log 10$, a dung beetle abundance was related to temperature $(\mathrm{F}=21.89 ; \mathrm{df}=1,38 ; \mathrm{p}<0.001$; Fig. 3a) but was not when related to precipitation $(\mathrm{F}=1.996$; $\mathrm{df}=1,38 ; \mathrm{p}=0.165 ;$ Fig. $3 \mathrm{~b}$ ). When relating precipitation and richness values, there was no clear relationship $(F=2.569 ; d f=1,38 ; p=0.117 ;$ Fig. $3 c)$. However, richness and temperature presented a clear relationship $(\mathrm{F}=19.37$; $\mathrm{df}=1,38 ; \mathrm{p}<0.001$; Fig. 3d).

The compositional similarity analysis revealed that the most similar sites were MRFB and TSPK (with a value of 0.564 ), the two conservation units located at the northwest region, followed by MOCE and the latter group (0.540). The sites with the lowest similarity were MRFB and VAFE (0.333) (Fig. 4).

In MRFB, the month of greatest richness and abundance was January/2017 (summer) $(\mathrm{S}=18, \mathrm{~N}=259)$ while July/2016 (winter) presented the lowest values $(\mathrm{S}=3, \mathrm{~N}=22)$. In TSPK, the month of greatest richness and abundance was October/2016 (spring) $(\mathrm{S}=19, \mathrm{~N}=1,272)$, while the month with the lowest richness and abundance was July/2017 (winter) $(\mathrm{S}=5, \mathrm{~N}=48)$. In MOCE and VAFE, the months of greatest richness and abundance were respectively November/2016 (spring) $(\mathrm{S}=18, \mathrm{~N}=593)$ and January/2017 (summer) $(\mathrm{S}=10, \mathrm{~N}=31)$, while the lower richness and abundance for MOCE was July/2016 (winter), and June/2017 (autumn) for VAFE, both with no specimens of Scarabaeinae sampled.

The NMDS revealed the formation of three groups with samples very close to each other (Fig. 5). In the first and largest grouping, the samples of January, February, March/2017, August, October, November, and December/2017 of MOCE, together with the October/2016 
Tab. I. Dung beetle species captured using pitfall traps baited with human feces in four sites with different levels of disturbance in Rio Grande do Sul state, Brazil, between May 2016 and July 2017 (TSPK, Turvo State Park; MFBR, Moreno Fortes Biological Reserve; MOCE, Morro do Cerrito; VAFE, District of Val Feltrina).

\begin{tabular}{|c|c|c|c|c|}
\hline \multirow{2}{*}{ Species } & \multicolumn{4}{|c|}{ Sites } \\
\hline & TSPK & MFBR & MOCE & VAFE \\
\hline Ateuchus aff. apicatus & 2 & 0 & 0 & 0 \\
\hline Ateuchus aff. carbonarius & 0 & 0 & 2 & 0 \\
\hline Ateuchus aff. robustus & 0 & 0 & 0 & 1 \\
\hline Canthidium aff. trinodosum & 120 & 305 & 678 & 43 \\
\hline Canthidium deplanatum Balthasar, 1939 & 0 & 1 & 1 & 0 \\
\hline Canthidium dispar Harold, 1867 & 2 & 11 & 3 & 2 \\
\hline Canthidium moestum Harold, 1867 & 0 & 3 & 17 & 2 \\
\hline Canthidium sp. & 0 & 0 & 2 & 0 \\
\hline Canthon aff. luctuosus & 0 & 4 & 11 & 0 \\
\hline Canthon angularis Harold, 1868 & 14 & 8 & 2 & 2 \\
\hline Canthon conformis Harold, 1868 & 0 & 0 & 0 & 2 \\
\hline Canthon laminatus Balthasar, 1939 & 0 & 4 & 0 & 0 \\
\hline Canthon lividus Blanchard, 1845 & 3 & 8 & 9 & 0 \\
\hline Canthon oliverioi (Pereira \& Martínez, 1956) & 2 & 1 & 26 & 0 \\
\hline Canthon quinquemaculatus (Castelnau, 1840) & 167 & 0 & 5 & 0 \\
\hline Canthon rutilans cyanescens Harold, 1868 & 36 & 21 & 324 & 25 \\
\hline Canthon seminitens Harold, 1868 & 9 & 1 & 2 & 13 \\
\hline Canthon sp. & 1 & 0 & 0 & 0 \\
\hline Chalcocopris hesperus Olivier, 1789 & 0 & 146 & 0 & 0 \\
\hline Coprophanaeus saphirinus (Sturm, 1826) & 7 & 18 & 22 & 2 \\
\hline Deltochilum brasiliense (Castelnau, 1840) & 26 & 75 & 15 & 0 \\
\hline Deltochilum furcatum Castelnau, 1840 & 22 & 3 & 0 & 0 \\
\hline Deltochilum morbillosum Burmeister, 1848 & 16 & 11 & 0 & 0 \\
\hline Deltochilum rubripenne (Gory, 1831) & 1 & 27 & 30 & 0 \\
\hline Deltochilum sculpturatum Felsche, 1907 & 0 & 0 & 0 & 1 \\
\hline Dichotomius aff. acuticornis & 1 & 4 & 5 & 0 \\
\hline Dichotomius assifer Eschscholtz, 1822 & 10 & 30 & 249 & 1 \\
\hline Dichotomius depressicolis (Harold, 1867) & 7 & 36 & 0 & 0 \\
\hline Dichotomius fissus Harold, 1867 & 0 & 3 & 0 & 0 \\
\hline Dichotomius mormon (Ljungh, 1799) & 46 & 13 & 0 & 0 \\
\hline Dichotomius nisus (Olivier, 1789) & 1 & 0 & 0 & 3 \\
\hline Dichotomius sericeus Harold, 1867 & 71 & 6 & 5 & 4 \\
\hline Dichotomius sp. & 0 & 1 & 0 & 0 \\
\hline Eurysternus aeneus Génier, 2009 & 1 & 0 & 0 & 0 \\
\hline Eurysternus caribaeus (Herbst, 1789) & 125 & 94 & 173 & 22 \\
\hline Eurysternus parallelus Castelnau, 1840 & 742 & 19 & 55 & 4 \\
\hline Homocopris sp. & 0 & 9 & 0 & 5 \\
\hline Ontherus azteca Harold, 1869 & 8 & 21 & 29 & 9 \\
\hline Ontherus sulcator (Fabricius, 1775) & 0 & 0 & 1 & 3 \\
\hline Onthophagus catharinensis Paulian, 1936 & 377 & 0 & 292 & 0 \\
\hline Onthophagus tristis Harold, 1873 & 80 & 0 & 214 & 2 \\
\hline Phanaeus splendidulus (Fabricius, 1781) & 0 & 0 & 0 & 1 \\
\hline Scybalocanthon nigriceps (Harold, 1868) & 1 & 420 & 0 & 0 \\
\hline Sulcophanaeus menelas (Castelnau, 1840) & 1 & 0 & 0 & 1 \\
\hline Uroxys sp. & 2 & 2 & 8 & 0 \\
\hline Zonocopris gibbicollis Harold, 1868 & 0 & 1 & 0 & 0 \\
\hline Number of species & 30 & 31 & 26 & 21 \\
\hline Number of individuals & 1901 & 1306 & 2180 & 148 \\
\hline
\end{tabular}




\section{(1) Sample-size-based rarefaction and extrapolation sampling curve}

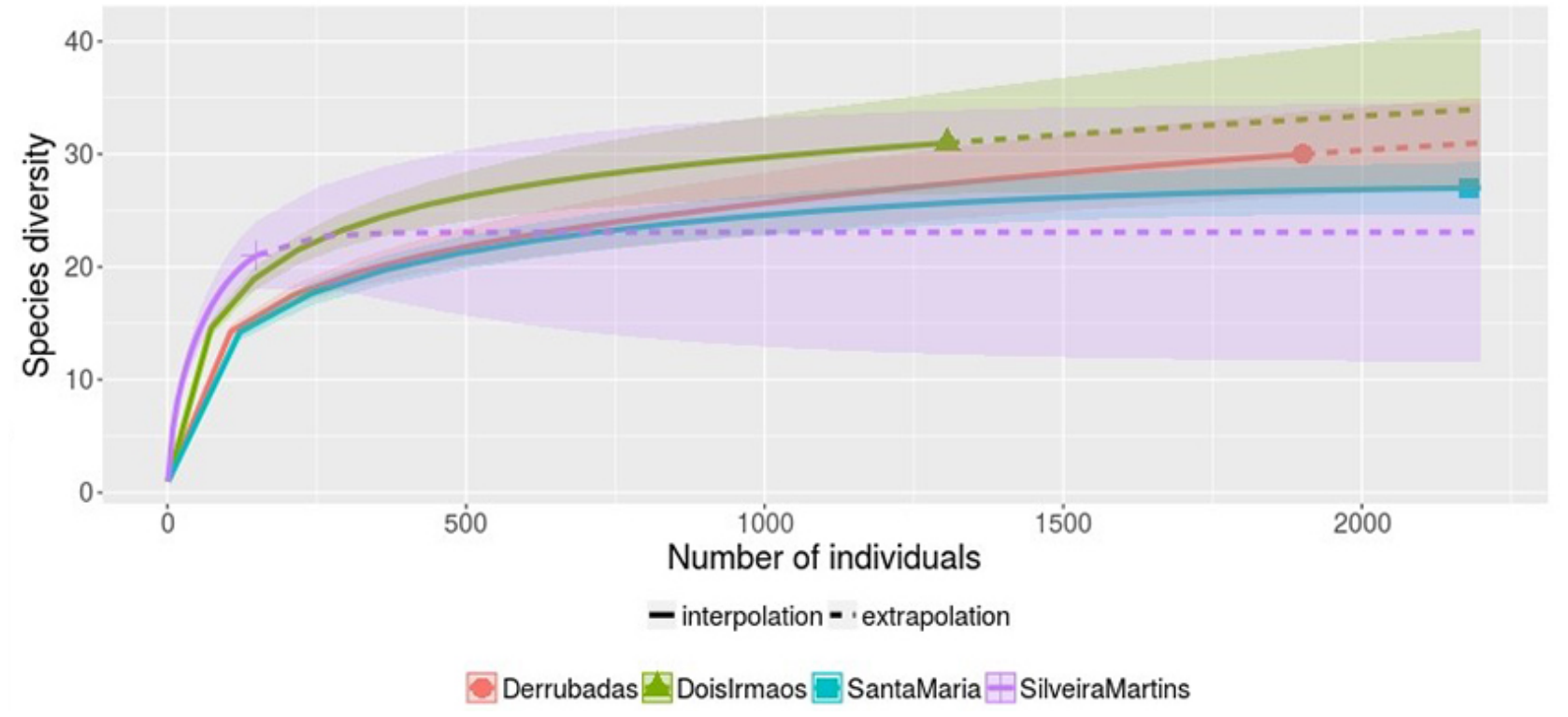

Fig. 2. Rarefaction and extrapolation curves of the assemblages of Scarabaeinae sampled in four Atlantic Forest sites in Rio Grande do Sul state, Brazil, during May 2016 to July 2017.
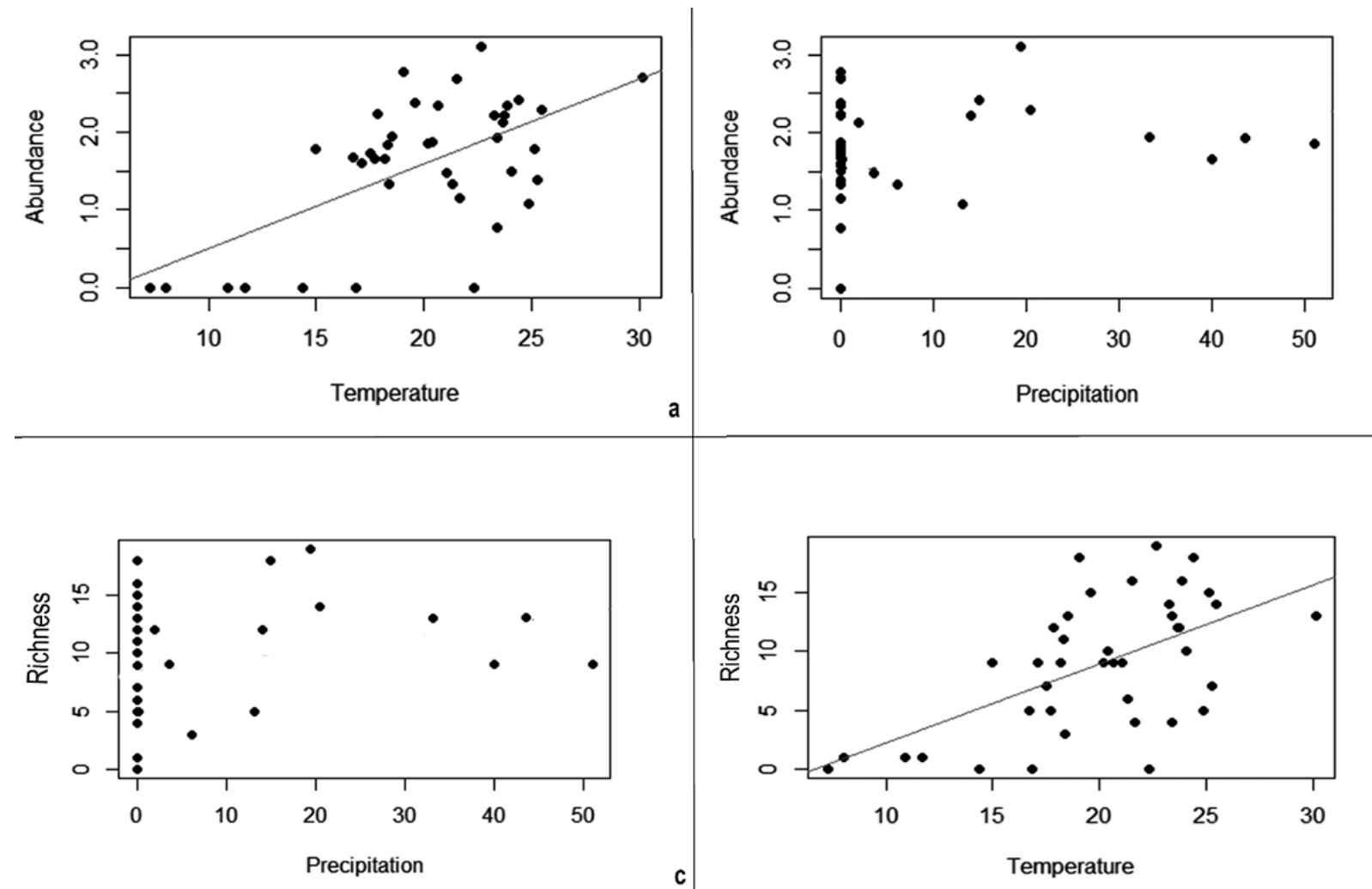

a

Fig. 3. Linear regression between the climatic variables (precipitation and temperature) and dung beetle abundance and richness sampled in Atlantic Forest sites of Rio Grande do Sul state (Turvo State Park, Moreno Fortes Biological Reserve, Morro do Cerrito, Val Feltrina) between May 2016 and July 2017. 


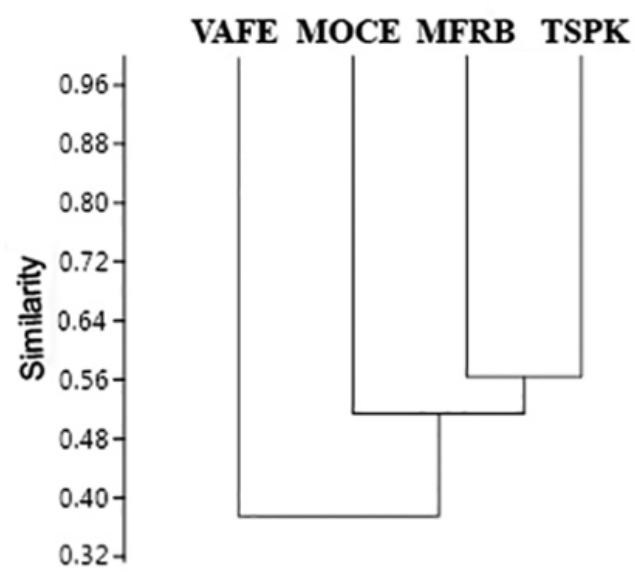

Fig. 4. Cluster analysis of the dung beetle similarity (Jaccard coefficient) between the four Atlantic Forest sites sampled in Rio Grande do Sul state, Brazil: Turvo State Park (TSPK); Moreno Fortes Biological Reserve (MRBR); Morro do Cerrito (MOCE); Val Feltrina (VAFE) between May 2016 and July 2017. sample, had a great similarity of species composition. The samples of October, November, and December/2016, January, February, and March/2017 of MRFB with the sample of the month of January/2017 of TSPK, form the second grouping. Finally, the samples of April/2017 of MOCE and TSPK form the third grouping.

Tab. II. Pielou equitability, Shannon-Wiener (H) and Simpson (1-D) diversity indexes derived from Scarabaeinae assemblages captured using pitfall traps baited with human feces in four sites with different levels of alteration in Rio Grande do Sul, southern Brazil (TSPK, Turvo State Park; MFRB, Moreno Fortes Biological Reserve; MOCE, Morro do Cerrito; VAFE, District of Val Feltrina).

\begin{tabular}{lcccc}
\hline \multirow{2}{*}{ Indexes } & \multicolumn{4}{c}{ Sites } \\
\cline { 2 - 5 } & TSPK & MFBR & MOCE & VAFE \\
\hline Shannon-Wiener (H) & 7.75 & 9.05 & 8.49 & 10.10 \\
Simpson (1-D) & 4.71 & 5.49 & 6.00 & 6.61 \\
Equitability (J) & 0.60 & 0.64 & 0.64 & 0.75 \\
\hline
\end{tabular}

NON-METRIC MULTIDIMENSIONAL SCALING

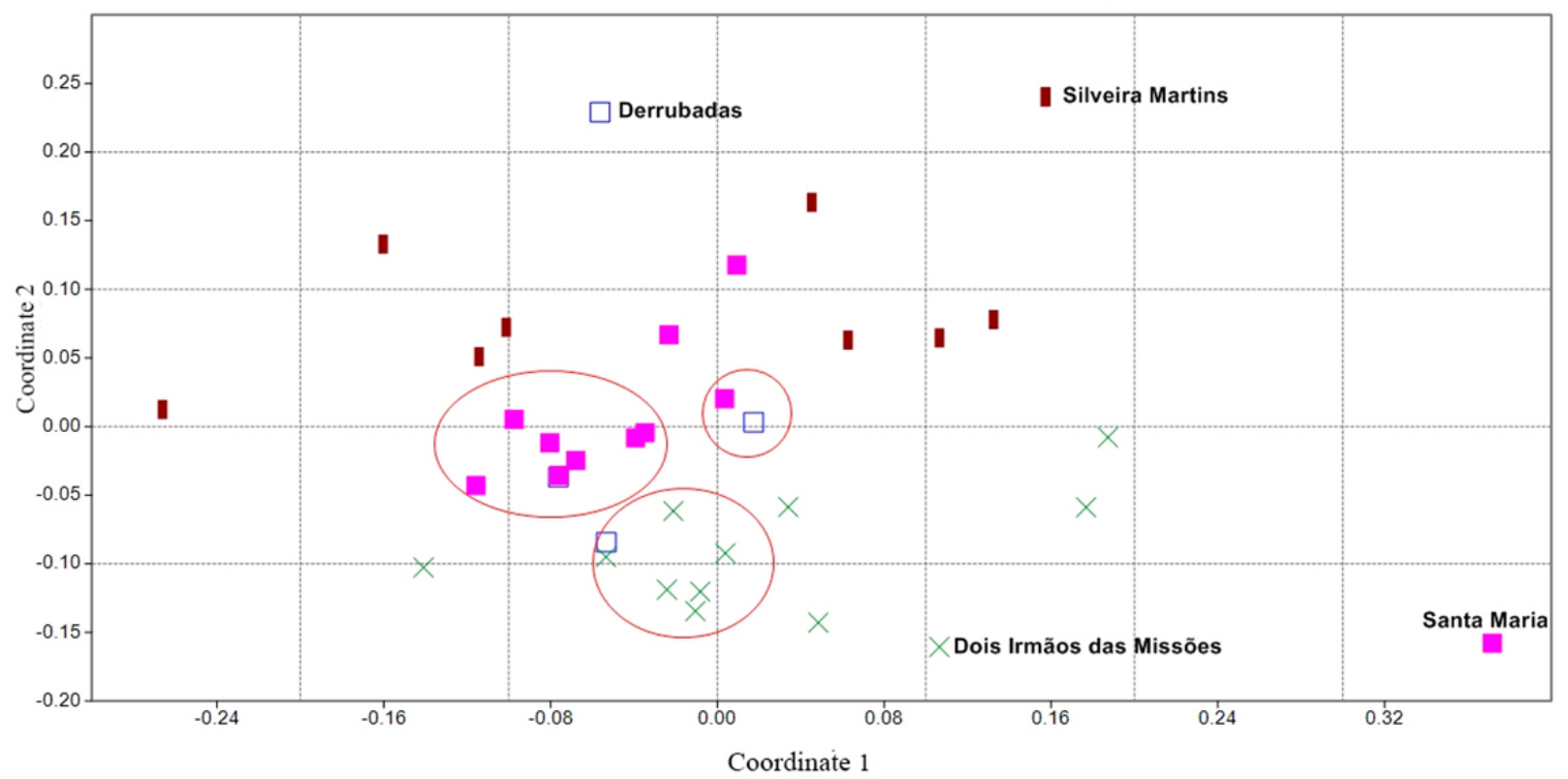

Fig. 5. Non-metric multidimensional scaling (Bray-Curtis coefficient) for samplings of the four Atlantic Forest sites sampled in Rio Grande do Sul state, Brazil, between May 2016 and July 2017. Red circles represent the most similar clusters.

\section{DISCUSSION}

The number of dung beetle species found (46) is relatively high when compared to previously produced works in the study regions (AUDINo et al., 2011; DA SILVA et al., 2011; DA SiLVA \& Di MARE, 2012; Lima et al., 2015). In a preliminary review of the species of Scarabaeinae from Rio Grande do Sul, Brazil (DA SILVA, 2011) and bibliographical review of subsequent years (DA SILVA \& Di MARE, 2012; VIEGAS et al., 2014; LimA et al., 2015;), it was verified that the following species constitute new records for the state of Rio
Grande do Sul: Canthidium deplanatum (Balthasar, 1939), Canthon conformis (Harold, 1868), Deltochilum furcatum (Castelnau, 1840), Dichotomius depressicolis (Harold, 1867), and Dichotomius fissus (Harold, 1867).

In this study, the pattern of occurrence of species was related to temperature, where hot months showed the greatest richness and abundance. This result corroborates those obtained by Hernández \& VAZ-DE-Mello (2009), who found more individuals and species occurring during summer, with a positive relationship between the number of species and average monthly temperature. A similar 
finding was observed in the present study, where the monthly temperature influenced the abundance positively. For each $1^{\circ} \mathrm{C}$ of temperature increase, dung beetle abundance increases by 0.023 (effect size).

To verify if the dung beetle assemblages show seasonal variation, Neves et al. (2010) compared rainy and dry seasons of Tropical Dry Forests. Seasonality of rainfall affected the community organization of dung beetles, which presented greater richness and abundance during rainy periods. In the rainy season, 2,748 individuals of 38 species of Scarabaeinae were recorded, while only four individuals were sampled in the dry season. In tropical rainforests, species diversity is greater in periods of higher precipitation (HILL, 1993; ANDRESEN, 2002). Dung beetles from northern Minas Gerais state, Brazil, demonstrate a peak in adult emergence for most dung beetle species at the beginning of the wet season (December), where $87 \%$ of the total of species and $85 \%$ of the total of individuals were collected (Novars et al., 2016). In Brazilian Cerrado, dung beetles showed a positive association between richness and abundance with precipitation and relative humidity; however, there was no correlation between richness and temperature; the largest occurrence of species and individuals of dung beetles were recorded in the rainy season (MiLHomem et al., 2003). ANDRADE et al. (2011) in a tropical transitional forest between Cerrado (Brazilian Savanna) and Amazon Forest in the state of Mato Grosso, Brazil, found that dung beetles are particularly sensitive to rainfall, showing a pronounced seasonality. In a tropical forest located at Southern Mexico, CABALLERo \& LEÓN-CORTÉZ (2012) verified that climatic seasonality had a profound effect on dung beetle community structure, where changes in Scarabaeinae diversity were particularly pronounced from dry to wet seasons. These results support the statement that dung beetle activity is higher in wetter months, evidencing that precipitation has great influence on the activity of Scarabaeinae species in tropical regions where temperature values do not show great variation.

Contrary, DA SiLva et al. (2013) found temperature as the main cause for the seasonality of dung beetles sampled in a subtropical region from southern Brazil, since the expressive richness and abundance of Scarabaeinae were predominantly collected in the spring (October), with 30 species, and the lowest values of richness and abundance found during the winter (eight species in July). Our results revealed similar patterns. Very low temperatures such as those occurring in winter tend to cause death or hibernation of dung beetles, which may pass through this unfavorable climatic period in the larval form (HALFFTER \& MATthews, 1966). Therefore, in subtropical and temperate regions, dung beetles are largely affected by temperature, showing a distinct pattern of seasonality, with higher abundance and richness in seasons with higher temperature, such as in spring and summer (Hernández \& VAZ-DE-Mello, 2009; DA Silva et al., 2013).

Both analyses of similarity resulted in large groupings of sites or samples that can be defined as the closest in space or time and consequently more similar. Most of them followed a pattern and can be explained by the succession of samplings, which occurred monthly in most sites. As the analysis deals with the similarity of samples, we can infer that they have similar environmental conditions and therefore were distributed very closely in the figure. Species of Scarabaeinae have variation in their composition between the studied sites, since few samples formed groupings among themselves, never being the samples representing the four sites in the same grouping. The highest similarity found in the cluster analysis occurred between the Conservation Units of MFRB and TSPK (consequently more preserved), while the largest difference when comparing species composition occurred between MFBR and VAFE, which presented the smallest number of species among the four sites sampled. When comparing abundance, i.e. NMDS analysis, the greatest difference was found between MOCE and VAFE, which also had the lowest number of individuals among the studied sites. These results confirm that individuals of Scarabaeinae can find more favorable conditions in more preserved environments (VIEGAS et al., 2014; Lima et al., 2015; NiERO \& HERNÁNDEZ, 2017) and thus presenting high abundances.

The seasons of greatest abundance and richness were spring and summer, being the months of October, November, and December those that presented the highest values. The months of June and July were those with the lowest richness and abundance, which is a common pattern since this group tends to pass unfavorable seasons in their larval form (HalfFter \& Matthews, 1966). High temperatures represent the period of greatest dung beetle abundance in subtropical regions of Brazil (HERNÁNDEZ \& VAZ-DE-MELLO, 2009; DA SiLVA et al., 2013; DA SiLVA \& HeRnándeZ, 2014). In the subtropical region, most sites demonstrate high species abundance and richness in early summer (HERNÁNDEZ \& VAZDE-Mello, 2009; DA SiLva et al., 2013, 2018). Therefore, we corroborate in this study that dung beetles show a well-defined seasonality in southern South America, where temperature, rather than precipitation, is frequently acknowledged as the main factor driving the seasonal variation in dung beetle species richness and abundance in this region.

Acknowledgments. We would like to thank Fernando Vaz-deMello (UFMT) for dung beetle identification. We also thank the Coordenação de Aperfeiçoamento de Pessoal de Nível Superior (CAPES, Code 001) for scholarships and Instituto Chico Mendes de Conservação da Biodiversidade (ICMBio) for permission to sample beetles. This study is dedicated to Rocco Alfredo Di Mare (in memoriam).

\section{REFERENCES}

Abot, A. R.; Puker, A.; Taira, T. L.; Rodrigues, S. R.; Korasaki, V. \& Oliveira, H. N. 2012. Abundance and diversity of coprophagous beetles (Coleoptera: Scarabaeidae) caught with a light trap in a pasture area of the Brazilian Cerrado. Studies on Neotropical Fauna and Environment 47(1):53-60.

Andrade, R. B.; Barlow, J.; Louzada, J.; Vaz-De-Mello, F. Z.; Souza, M.; Silveira, J. M. \& Cochrane, M. A. 2011. Quantifying responses of dung beetles to fire disturbance in tropical forests: the importance of trapping method and seasonality. PLoS ONE 6(10):e26208.

ANDRESEN, E. 2002. Dung beetles in a Central Amazonian rainforest and their ecological role as secondary seed dispersers. Ecological Entomology 27(3):257-270.

ANDRESEN, E. 2005. Effects of Season and vegetation type on community organization of dung beetles in a Tropical Dry Forest. Biotropica 37(2):291-300. 
Audino, L. D.; da Silva, P. G.; Nogueira, J. M.; Moraes, L. P. \& VaZDE-Mello, F. Z. 2011. Scarabaeinae (Coleoptera, Scarabaeidae) de um bosque de eucalipto introduzido em uma região originalmente campestre. Iheringia, Série Zoologia 101(1-2):121-126.

Begon, M.; Townsend, C. R. \& Harper, J. L. 2007. Ecologia: de indivíduos a ecossistemas. 4ed. Porto Alegre, Artmed. 752p.

Caballero, U. \& León-Cortéz, J. L. 2012. High diversity beetle assemblages attracted to carrion and dung in threatened tropical oak forests in Southern Mexico. Journal of Insect Conservation 16(4):537-547.

Chao, A.; Ma, K. H. \& Hsieh, T. C. 2016. iNEXT (iNterpolation and EXTrapolation) Online: Software for Interpolation and Extrapolation of Species Diversity. Program and User's Guide published at http:// chao.stat.nthu.edu.tw/wordpress/software_download/.

Colwell, R. K. \& Elsensohn, J. E. 2014. EstimateS turns 20: statistical estimation of species richness and shared species from samples, with non-parametric extrapolation. Ecography 37(1):609-613.

DA SILVA, P. G. 2011. Dung beetles (Coleoptera: Scarabaeidae: Scarabaeinae) of two non-native habitats in Bagé, Rio Grande do Sul, Brazil. Zoological Studies 50(5):546-559.

Da Silva, P. G.; Audino, L. D.; Nogueira, J. M.; Moraes, L. P. \& VazDE-Mello, F. Z. 2012. Escarabeíneos (Coleoptera: Scarabaeidae: Scarabaeinae) de uma área de campo nativo no bioma Pampa, Rio Grande do Sul, Brasil. Biota Neotropica 12(3):246-253.

DA SiLVA, P. G. \& Hernández, M. I. M. 2014. Local and regional effects on community structure of dung beetles in a mainland-island scenario. PLOS ONE 9(10):e111883.

da Silva, P. G.; Lobo, J. M.; Hensen, M. C.; Vaz-de-Mello, F. Z. \& HernáNDEZ, M. I. M. 2018. Turnover and nestedness in subtropical dung beetle assemblages along an elevational gradient. Diversity and Distributions 24(9): 1277-1290.

Da Silva, P. G.; Vaz-De-Mello, F. Z. \& Di Mare, R. A. 2011. Guia de identificação das espécies de Scarabaeinae (Coleoptera: Scarabaeidae) do município de Santa Maria, Rio Grande do Sul, Brasil. Biota Neotropica 11(4):329-345.

DA SilVA, P. G. \& Di MARE, R. A. 2012. Escarabeíneos copro-necrófagos (Coleoptera, Scarabaeidae, Scarabaeinae) de fragmentos de Mata Atlântica em Silveira Martins, Rio Grande do Sul, Brasil. Iheringia, Série Zoologia 102(2): 197-205.

Da Silva, P. G; Vaz-De-Mello, F. Z. \& Di Mare, R. A. 2013. Diversity and seasonality of Scarabaeinae (Coleoptera: Scarabaeidae) in forest fragments in Santa Maria, Rio Grande do Sul, Brazil. Anais da Academia Brasileira de Ciências 85(1):679-697.

Filgueiras, B. K. C.; Liberal, C. N.; Aguiar, C. D. M.; Hernández, M. I. M. \& IANNUZZI, L. 2009. Attractivity of omnivore, carnivore and herbivore mammalian dung to Scarabaeinae (Coleoptera, Scarabaeidae) in a tropical Atlantic rainforest remnant. Revista Brasileira de Entomologia 53(3):422-427.

Halffter, G. \& Matthews, E. G. 1966. The natural history of dung beetles in the subfamily Scarabaeidae (Coleoptera, Scarabaeidae). Folia Entomológica Mexicana 12(14):1-312.

Hammer, O.; HarPeR, D. A. T. \& RYAn, P. D. 2001. PAST: Paleontological Statistics software package for education and data analysis. Palaeontologia Electronica 4(1): 1-9.

HernándeZ, M. I. M. \& VAZ-De-Mello, F. Z. 2009. Seasonal and spatial species richness variation of dung beetle (Coleoptera, Scarabaeidae $s$. str.) in the Atlantic Forest of southeastern Brazil. Revista Brasileira de Entomologia 53(4):607-613.

HILL, C. J. 1993. The species composition and seasonality of an assemblage of tropical Australian dung beetles (Coleoptera: Scarabaeidae: Scarabaeinae). Australian Entomologist 20(4):121-126.

HSIEH, T. C.; MA, K. H. \& CHAO, A. 2016. iNEXT: an R package for rarefaction and extrapolation of species diversity (Hill numbers). Methods in Ecology and Evolution 7(1):1451-1456.

IBGE - Instituto Brasileiro de Geografia e Estatística. 2011. Cidades - RS. Available at <http://www.ibge.gov.br/cidadesat/painel/painel. php?codmun=432065>. Accessed on March 21, 2016.

IBGE - Instituto Brasileiro de Geografia e Estatística. 2012. Manual técnico da vegetação brasileira. Available at $<\mathrm{http}$ ://biblioteca. ibge.gov.br/visualizacao/livros/liv63011.pdf > . Accessed on March 22, 2016.
ICMBio - Instituto Chico Mendes de ConservaÇão da Biodiversidade. 2008. Plano de Manejo da Reserva Biológica Moreno Fortes. Brasília, ICMBio. 390p.

ICMBio - Instituto Chico Mendes de ConservaÇão da Biodiversidade. 2005. Plano de Manejo do Parque Estadual do Turvo. Brasília, ICMBio. 348p.

inMET - Instituto Nacional de Meteorologia. 2018. Estações e dados. Available at $<\mathrm{http}: / /$ www.inmet.gov.br/portal/> . Accessed on January 15, 2018.

Kuinchtner, A. \& Buriol, G. A. 2001. Clima do estado do Rio Grande do Sul segundo a classificação climática de Köppen e Thornthwaite. Disciplinarum Scientia. Série: Ciências Exatas 2(1):171-182.

Lima, J. D. N.; Silva, V. C.; Bianchi, V.; Da Silva, P. G. \& Di Mare, R. A. 2015. Estrutura e organização de assembleias de Scarabaeinae (Coleoptera, Scarabaeidae) em diferentes fitofisionomias no sul do Brasil. Iheringia, Série Zoologia 105(4):393-402.

MAGURRAN, A. E. 2004. Measuring biological diversity. Oxford, Blackwell Science. 256p.

Maluf, J. R. T. 2000. Nova classificação climática do Estado do Rio Grande do Sul. Revista Brasileira de Agrometeorologia 8(1):141-150.

Milhomem, M. S.; VAZ-De-Mello, F. Z. \& Diniz, I. R. 2003. Técnicas de coleta de besouros copronecrófagos no Cerrado. Pesquisa Agropecuária Brasileira 38(11):1249-1256.

Morelli, E.; GonzÁlez-Vainer, P. \& Baz, A. 2002. Coprophagous beetles (Coleoptera: Scarabaeoidea) in Uruguayan Prairies: abundance, diversity and seasonal occurrence. Studies on Neotropical Fauna and Environment 37(1):53-57.

Neves, F. S.; Oliveira, V. H. F.; Espírito-Santo, M. M.; VaZ-De-Mello, F. Z.; Louzada, J.; Azofeifa, A. S. \& Fernandes, G. W. 2010. Successional and seasonal changes in a community of dung beetles (Coleoptera: Scarabaeinae) in a Brazilian Tropical Dry Forest. Natureza \& Conservação 8(2): 160-164.

Nichols, E.; LaRsen, T.; Spector, S.; Davis, A. L.; Escobar, F.; Favila, M. \& VulineC, K. 2007. Global dung beetle response to tropical forest modification and fragmentation: a quantitative literature review and meta-analysis. Biological Conservation 137(1):1-19.

Nichols, E.; SPeCtor, S.; LouZAda, J.; LARSEn, T.; AMEZQuita, S. \& FaVILA, M. E. 2008. Ecological functions and ecosystem services provided by Scarabaeinae dung beetles. Biological Conservation 141(1):1461-1474.

Niero, M. M. \& Hernández, M. I. M. 2017. Influência da paisagem nas assembleias de Scarabaeinae (Coleoptera: Scarabaeidae) em um ambiente agrícola no sul de Santa Catarina. Biotemas 30(3):37-48.

Novais, S.; Evangelista, L. A.; Reis-Júnior, R. \& Neves, F. S. 2016. How does dung beetle (Coleoptera: Scarabaeidae) diversity vary along a rainy season in a tropical dry forest? Journal of Insect Science 16(1):1-6.

Pereira, P. R. B.; Garcia-Netto, L. R.; Borin, C. J. A. \& Sartori, M. G. B. 1989. Contribuição à geografia física do município de Santa Maria: unidades de paisagem. Geografia, Ensino e Pesquisa 3:37-68.

Pielou, E. C. 1966. The measurement of diversity in different types of biological collections. Journal of Theoretical Biology 13:131-144.

Salomão, R. P. \& IANNUZZI, L. 2015. Dung beetle (Coleoptera, Scarabaeidae) assemblage of a highly fragmented landscape of Atlantic forest: from small to the largest fragments of northeastern Brazilian region. Revista Brasileira de Entomologia 59(2):126-131.

TARASOv, S. \& GÉNIER, F. 2015. Innovative Bayesian and parsimony phylogeny of dung beetles (Coleoptera, Scarabaeidae, Scarabaeinae) enhanced by ontology-based partitioning of morphological characters. PLOS ONE 10(3): e0116671.

VAZ-DE-Mello, F. Z. 2000. Estado de conhecimento dos Scarabaeidae. (Coleoptera: Scarabaeoidea) do Brasil. In: MARTín-PIERA, F.; Morrone, J. J. \& MeLIC, A. eds. Hacia un proyecto CYTED para el inventario y estimación de la diversidad entomológica en Iberoamérica. Zaragoza, Sociedad Entomológica Aragonesa, p. 181-195.

VAZ-De-Mello, F. Z. 2019. Scarabaeinae in Catálogo Taxonômico da Fauna do Brasil. PNUD. Available at $<$ http://fauna.jbrj.gov.br/fauna/ faunadobrasil/127498>. Accessed on May 24, 2019.

Viegas, G.; Stenerta, C.; Schulz, U. H. \& MaltchiKa, L. 2014. Dung beetle communities as biological indicators of riparian forest widths in southern Brazil. Ecological Indicators 36:703-710.

Wolda, H. 1988. Insect seasonality: Why? Annual Review of Ecology and Systematics 19:1-18. 